\title{
LOCALISED CORROSION OF STAINLESS STEELS 316L AND 2205 IN SYNTHETIC BENTONITE PORE WATER AND BENTONITE SLURRY
}

\author{
Jan Stoulil ${ }^{1) *}$, Liudmila Pavlova ${ }^{1)}$, Milan Kouřril ${ }^{1)}$ \\ 1) University of Chemistry and Technology Prague, Department of Metals and Corrosion \\ Engineering
}

Received: 07.11.2018

Accepted: 10.01.2019

${ }^{*}$ Corresponding author: jan.stoulil@vscht.cz; +420 22044 3750; University of Chemistry and Technology, Department of Metals and Corrosion Engineering, Technická 5, Prague 16628, Czech Republic

\begin{abstract}
One concept for Czech canister construction for deep geological repository considers stainless steel as an inner case material. Corrosion resistance to localised (pitting/crevice) corrosion and stress corrosion cracking of austenitic stainless steel 316L and duplex steel 2205 was studied. The environment was synthetic bentonite pore water (SBPOW) of domestic bentonite BaM, or a slurry of bentonite in SBPOW. Tests were carried out between $40{ }^{\circ} \mathrm{C}$ and $90{ }^{\circ} \mathrm{C}$ under anaerobic conditions of a nitrogen atmosphere. The following methods were used for evaluation: potentiostatic tests at oxidation-reduction potential of the environment, long-term exposure tests in SBPOW and slurry, slow strain rate tensile test (SSRT), exposure test of U-bends, and optical microscopy. Results showed no susceptibility of either material to stress corrosion cracking. No localised corrosion was observed up to $70{ }^{\circ} \mathrm{C}$. There was no localised attack observed in SBPOW at $90{ }^{\circ} \mathrm{C}$, but there was localised corrosion detected in the bentonite slurry. Forced breakdown of the passive layer during SSRT, and artificial crevices (O-rings), showed no effect on localised corrosion propagation. The detrimental effect was probably a result of the adsorption ability of the bentonite particles, which allowed breakdown of passive layer and disabled repassivation of metastable pits.
\end{abstract}

Keywords: deep geological repository, stainless steel, bentonite, localised corrosion, stress corrosion cracking

\section{Introduction}

The Czech concept [1-8] of a HLW canister for deep geological repository considers three combinations of metallic material inner/outer case:

- stainless steel/carbon steel,

- carbon steel/copper,

- carbon steel/TiPd alloy.

In the first concept, a uniformly (predictable) corroding carbon steel case should overcome at least the aerobic period, when crevice corrosion would arise for sure on stainless steels. This work should verify what conditions in a repository could be acceptable for stainless steel. All oxygen is supposed to be consumed relatively fast in the repository, but the temperature could still be high, at $90{ }^{\circ} \mathrm{C}$. The final temperature of the repository will be close to that of the host granitic rock. A conservative value is $40^{\circ} \mathrm{C}$, but the real temperature will probably be lower.

According to the mechanism of crevice corrosion, this kind of attack, based on differential aeration inside and outside the crevice is not very probable under anaerobic conditions. Pang and 
Blackwood have published a study on Ti alloys, when anaerobic conditions led to activation [9], but this does not seem possible for stainless steel containing $\mathrm{Cr}$ and $\mathrm{Ni}$. Stainless steels are susceptible to pitting corrosion in anaerobic conditions in the presence of sulphides. Superficial $\mathrm{FeS}$ working as cathode to the surrounding matrix is supposed to be responsible for the pitting $[10,11]$, but further studies have shown that there is inevitable oxidation of sulphide to thiosulphate by residual oxygen [12-14].

Stainless steel can be susceptible in repository environment under certain circumstances also to stress corrosion cracking [15, 16] or hydrogen embrittlement [17]. Stainless steel was considered also in USA [18] or Belgian [19] concept. When stainless steel is not attacked locally [20, 21], the corrosion rate in passivity seems reasonable for long term storage [22, 23].

The aim of this study is to verify the possibilities of crevice/pitting corrosion and stress corrosion cracking in anaerobic bentonite pore solution and bentonite slurry.

\section{Experimental}

\subsection{Potentiostatic tests at $\mathbf{E}_{\mathrm{RED} / 0 \mathrm{x}}$}

These experiments were carried out in an $800 \mathrm{ml}$ beaker equipped with special PTFE cap for the working electrode (sample), counter electrode, reference electrode, thermometer, and nitrogen/air inlet. The beaker was heated on a plate controlled by a digital thermometer. All experiments were carried out at $90{ }^{\circ} \mathrm{C}$ in synthetic bentonite pore water (SBPOW), the composition of which is given in Table 1. SBPOW was estimated as equilibrium pore solution of saturated Czech domestic bentonite BaM with dry density $1600 \mathrm{~kg} \cdot \mathrm{m}^{-3}$. Samples were rods of stainless steel, $10 \mathrm{~mm}$ in diameter and $100 \mathrm{~mm}$ long. Materials used for these tests were austenitic stainless steel $316 \mathrm{~L}$ and duplex stainless steel 2205. The chemical composition of both materials is given in Table 2. Samples were polished by emery paper P120 prior to all measurements.

Table 1 Chemical composition of synthetic bentonite pore water (SBPOW)

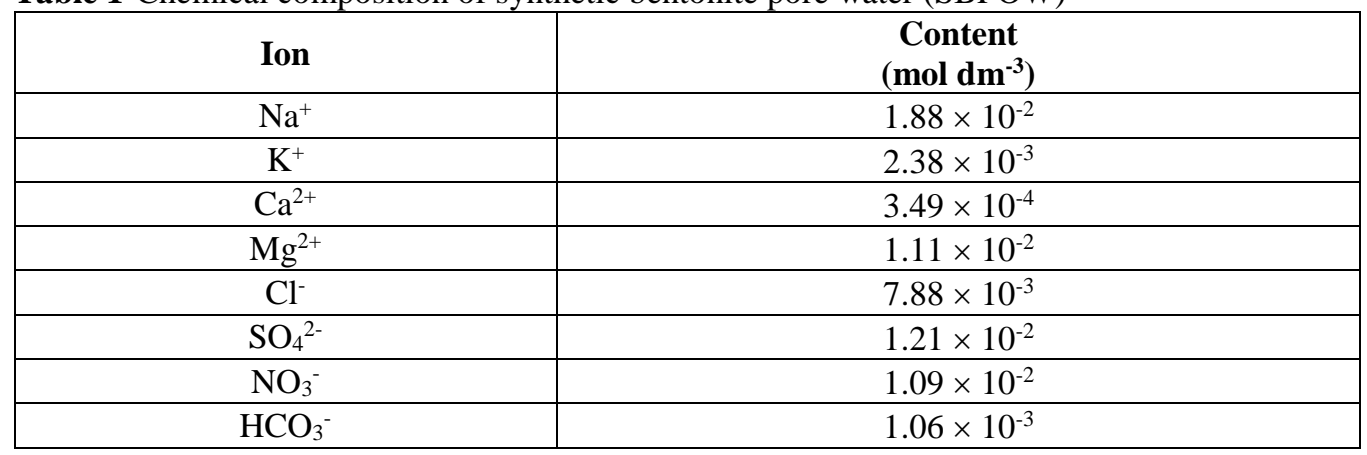

Samples were supplied with five O-rings at $10 \mathrm{~mm}$ spacing, working as artificial crevices. Those were placed in the lower part of the rod, because only $70 \mathrm{~mm}$ of the rods length was exposed to the solution. Platinum sheet $(5 \times 5 \mathrm{~mm})$ served as counter electrode, and saturated silver-silver chloride electrode (ACLE) as reference. The reference electrode was placed in the salt bridge filled with SBPOW. Experiments were carried out in aerated and in deaerated conditions. The environment in the repository should be anaerobic; the experiments with aerated SBPOW were made to verify the influence of residual oxygen or of a technological defect from manufacturing when the inner case would be exposed to an aerated environment. The beaker was aerated for $1 \mathrm{~h}$ by air bubbling or deaerated by nitrogen, with simultaneous free corrosion potential ( $\left.\mathrm{E}_{\mathrm{CORR}}\right)$ 
settling. Potentiostatic polarisation at oxidation-reduction potential ( $\left.\mathrm{E}_{\mathrm{RED} / \mathrm{Ox}}\right)$ was started after that period. $\mathrm{E}_{\mathrm{RED} / \mathrm{OX}}$ was measured prior to these experiments and the average value was estimated to be $122 \mathrm{mV} / \mathrm{ACLE}$ for aerated SBPOW and $-65 \mathrm{mV} / \mathrm{ACLE}$ for deaerated. The chloride content was increased approximately every $5 \mathrm{~min}$ by addition of concentrated solution of $\mathrm{NaCl}$ to 3,10, 33 and 100-fold relative to the original value.

Table 2 Chemical composition of materials (wt.\%)

\begin{tabular}{|c|c|c|c|c|c|c|c|c|c|}
\hline Sample & Mark & $\mathbf{C}$ & Si & Mn & P & S & Cr & Ni & Mo \\
\hline 316L & A & 0.021 & 0.25 & 1.88 & 0.044 & 0.028 & 16.70 & 10.60 & 2.11 \\
\hline 2205 & D & 0.021 & 0.36 & 1.54 & 0.029 & 0.001 & 22.80 & 5.43 & 2.82 \\
\hline
\end{tabular}

\subsection{Exposure tests}

These tests were carried out in special $1500 \mathrm{ml}$ vessels with silicone sealing for prevention of oxygen access. Flasks were filled with SBPOW or bentonite slurry. The bentonite slurry was prepared 1:1 (w/w) with SBPOW to achieve equilibrium quickly. Rod samples with five O-rings were placed in vessels with SBPOW, while bare rods were placed in vessels with the slurry. Four austenitic and four duplex samples were exposed separately. Vessels were deaerated by nitrogen $(99.99 \%)$ in the glovebox for four days and exposed at $90{ }^{\circ} \mathrm{C}$ for six months and vessels at $40{ }^{\circ} \mathrm{C}$ for nine months.

Additionally were carried out experiments in order to estimate critical temperature for localised attack for both materials. This experiment was aggravated by addition of iron powder into the bentonite. The ratio of iron powder and bentonite was 1:3 (w/w). This dry mixture was mixed with SBPOW solution 1:1 (w/w) and left 1 week in ambient atmosphere to partially corrode the iron powder particles. Then was the vessel with slurry placed into the glovebox deaerated with nitrogen $(99.99 \%)$ for four days. After deaeration the samples were inserted into vessels and those were sealed. Vessels were exposed at $40,50,60$ or $70{ }^{\circ} \mathrm{C}$ with duration of 6 months.

U-bend samples were also exposed. They were prepared from 30 x $130 \mathrm{~mm}$ sheets, bent over a $20 \mathrm{~mm}$ spike and fixed with bolts. Thickness of the austenitic sheet was $3 \mathrm{~mm}$ and duplex steel 2 $\mathrm{mm}$. Two U-bend samples of each material were exposed at $90{ }^{\circ} \mathrm{C}$ for four months after deaeration and sealing in glovebox as mentioned above.

\section{Slow strain rate tensile test}

Rod samples were machined to reveal the working part in the middle of the rod (see Fig. 1). The working part was $4 \mathrm{~mm}$ in diameter and $10 \mathrm{~mm}$ long. Samples were subjected to slow strain rate tensile tests in SBPOW at $90{ }^{\circ} \mathrm{C}$. Blank samples were exposed in demineralised water. The relative strain rate was $1.32 \times 10^{-6} \mathrm{~s}^{-1}$ (absolute $1.14 \mathrm{~mm} \mathrm{day}^{-1}$ ). Samples were tested in SBPOW under different conditions: aerated/deaerated; increased chloride concentration 100-fold relative to original value; or a presence of heat flux. This was achieved by electrical heating using an external DC source. Input current was $2.7 \mathrm{~A}$ and voltage drop of $0.54 \mathrm{~V}$ at the working part was measured. Approximate heat flux from sample to solution was $11.6 \mathrm{~kW} \mathrm{~m}{ }^{-2}$, which is 100 -fold higher than a real canister heating in a repository.

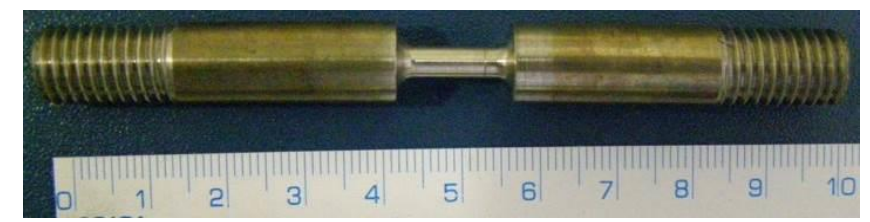

Fig. 1 Sample for SSRT test of stress corrosion cracking 


\section{Results}

\subsection{Potentiostatic tests at ERED/Ox $_{\text {R }}$}

Curve records of both materials in deaerated SBPOW are given in Fig. 2. Both types of stainless steel remained passive when polarised to $\mathrm{E}_{\mathrm{RED} / \mathrm{OX}}$ of deaerated SBPOW, even in the case of 100fold chloride content addition. The time of polarisation between each chloride addition was prolonged in one case, in order to observe the influence of time, but this prolongation did not lead to activation.

The same situation was observed for material 2205 under polarisation to $\mathrm{E}_{\mathrm{RED} / \mathrm{Ox}}$ of aerated SBPOW (Fig. 3). In contrast, material 316L was activated in aerated environment in all measurements when 10-fold chloride content was added (Fig. 4).

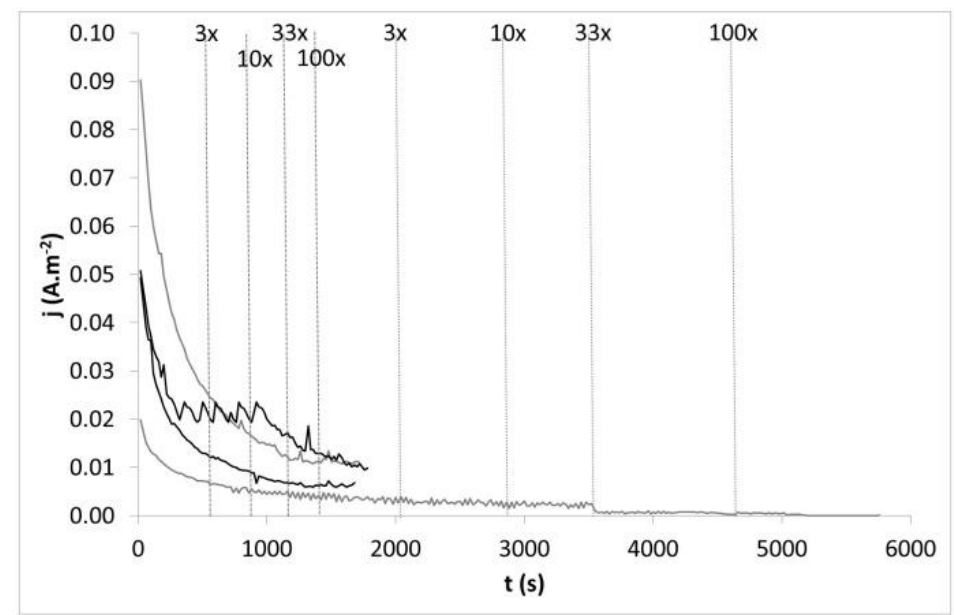

Fig. 2 Potentiostatic test in nitrogen-deaerated SBPOW at $-65 \mathrm{mV} / \mathrm{ACLE}$. Black curves 2205; Grey curves - 316L. Dashed vertical lines show additions of chlorides

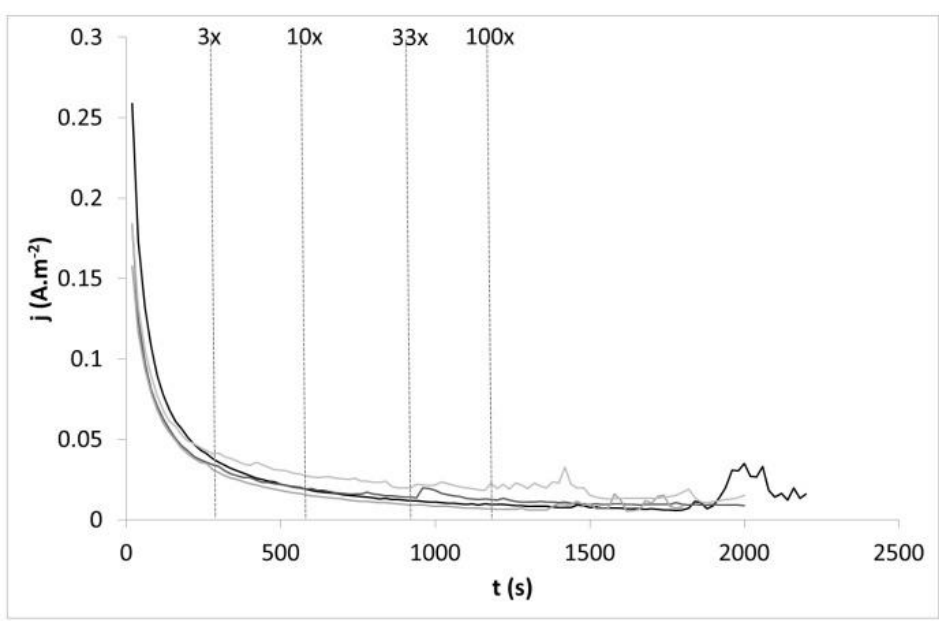

Fig. 3 Potentiostatic test in aerated SBPOW at $122 \mathrm{mV} /$ ACLE. Four samples of material 2205. Dashed vertical lines show additions of chlorides 


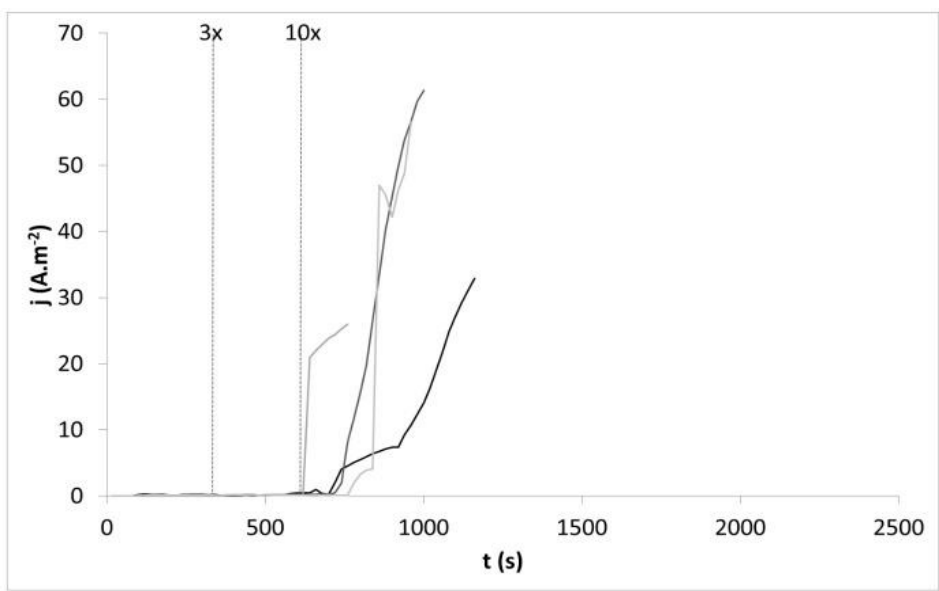

Fig. 4 Potentiostatic test in aerated SBPOW at $122 \mathrm{mV} /$ ACLE. Four samples of material 316L. Dashed vertical lines show additions of chlorides.

\subsection{Exposure tests}

Long-term exposure with artificial crevices (O-rings) in deaerated SBPOW at $90{ }^{\circ} \mathrm{C}$ did not reveal any corrosion attack. Detail of the surface under the crevice-forming O-ring is shown in Fig. 5. The surface is clear, and non-shielded surfaces outside a crevice were covered by calcareous deposit formed from unstable SBPOW at high temperature.

All samples of both materials showed significant localised attack after the exposure in deaerated bentonite slurry at $90{ }^{\circ} \mathrm{C}$ (see Fig. 6). These pits are present on the entire surface of the samples. They do not show the classical shape of pitting corrosion; they are shallow and have open mouths, as can be seen on the cross-cut in Fig. 7. This type of localised attack (controlled by diffusion through salt cap over pit mouth) was published by Munoz and Schild [24] on material 309 in deaerated brines according to German repository concept.

A summary of mass loss evaluation is given in Table 3. Neither mass loss were estimated nor the localised attack was observed visually up to $70{ }^{\circ} \mathrm{C}$ in bentonite slurry even when contaminated by iron corrosion products, which could be in real conditions form carbon steel outer case. It seems that $70{ }^{\circ} \mathrm{C}$ is save temperature for both types of stainless steel for exposure in repository environment. Localised attack could arise at $90{ }^{\circ} \mathrm{C}$ in bentonite slurry as mentioned above. The mass loss was higher in material 2205, but the deviation was very high, thus there is not necessarily a significant difference between the materials. Despite the mass loss even in local area is not high, it is unacceptable for extreme canister lifetime.

Table 3 Summary mass loss results $\left(\mathrm{g} \cdot \mathrm{m}^{-2} \cdot \mathrm{a}^{-1}\right)$ after 6 months exposure tests in bentonite-based environments

\begin{tabular}{|c|c|c|c|c|c|c|c|c|}
\hline $\begin{array}{c}\text { Temperature } \\
\left.\text { ( }{ }^{\circ} \mathbf{C}\right)\end{array}$ & \multicolumn{3}{|c|}{40} & 50 & 60 & 70 & \multicolumn{2}{|c|}{90} \\
\cline { 1 - 9 } Environment & SBPOW & BaM & BaM+Fe & BaM+Fe & BaM+Fe & BaM+Fe & SBPOW & BaM \\
\hline Material & 0 & 0 & 0 & 0 & 0 & 0 & 0 & $0.75 \pm 0.14$ \\
\hline $316 \mathrm{~L}$ & 0 & 0 & 0 & 0 & 0 & 0 & 0 & $1.62 \pm 1.20$ \\
\hline 2205 & 0 &
\end{tabular}

("SBPOW"-exposure in SBPOW with artificial crevices; "BaM"-slurry of bentonite BaM and SBPOW; "BaM+Fe"-slurry of bentonite BaM, iron powder and SBPOW) 
U-bend samples were also attacked locally after exposure in bentonite slurry at $90{ }^{\circ} \mathrm{C}$, but there was not observed localisation of the attack at the most strained sites of the bend. Pits were on the entire surface, similarly to the rod samples in the previous experiment. No corrosion cracks were observed on the bend surface.

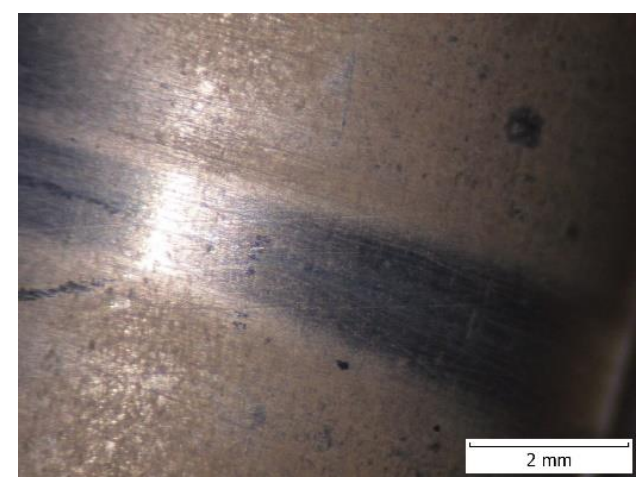

Fig. 5 Sample area of 2205 (D) rod, surrounding O-ring artificial crevice, after six-month exposure at $90{ }^{\circ} \mathrm{C}$ in nitrogen-deaerated SBPOW

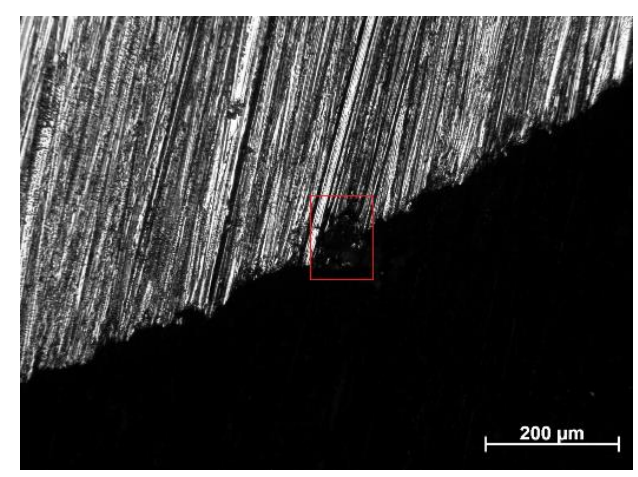

Fig. 7 Detail cross-cut of a pit on the 316L (A) sample after six-month exposure at $90{ }^{\circ} \mathrm{C}$ in nitrogendeaerated bentonite slurry

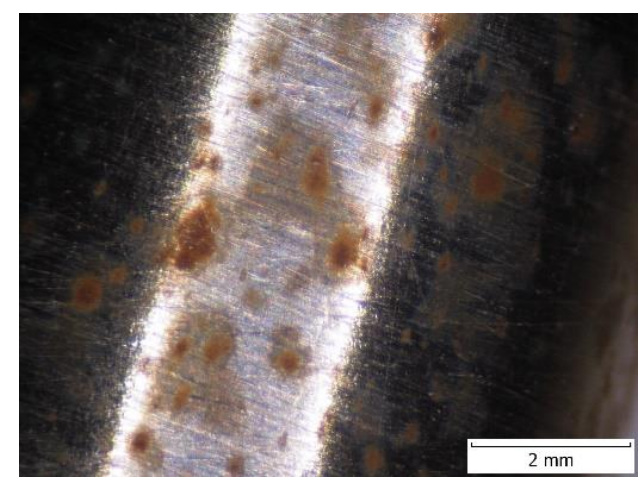

Fig. 6 Sample surface of 316L (A) rod after six-month exposure at $90{ }^{\circ} \mathrm{C}$ in nitrogen-deaerated bentonite slurry

\subsection{Slow strain rate tensile test}

A summary of all SSRT tests in deaerated SBPOW is given in Fig. 8. Despite the fact that the passive layer was mechanically forced to break down, no stress corrosion cracking was observed under any tested conditions. The environment was enriched in chloride content and heat flux was employed, but it did not lead to stress corrosion cracking. All samples showed only mechanical cracking with a typical 'neck' on the working part of the samples (see Fig. 9). 


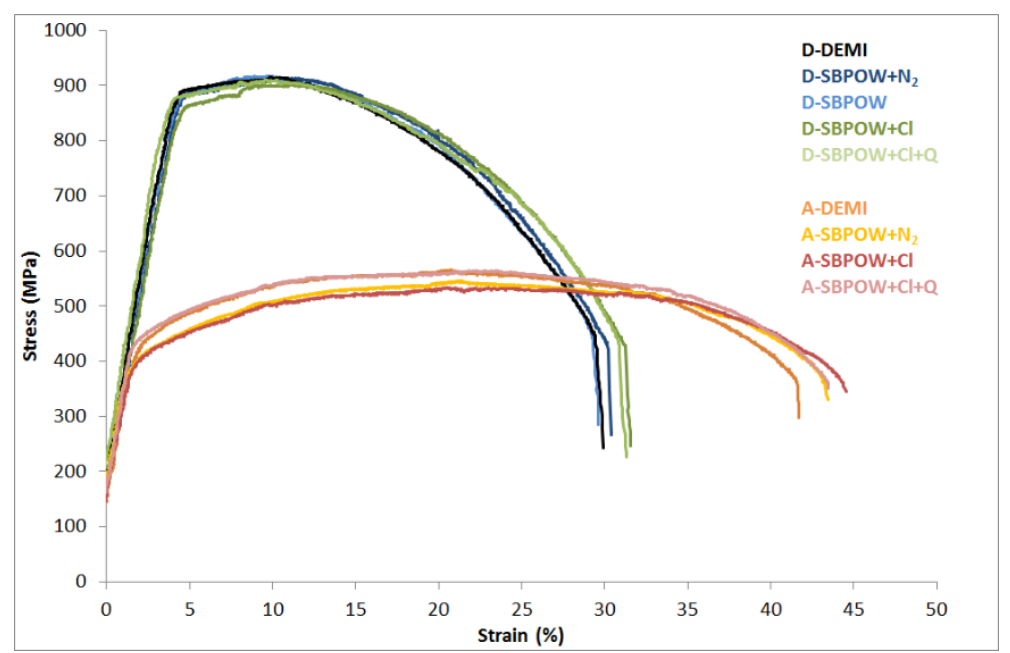

Fig. 8 Summary of stress-strain records of both materials - 2205 (D) and 316L (A) - obtained by SSRT test under different conditions

('DEMI'- test in $90{ }^{\circ} \mathrm{C}$ DEMI water; 'SBPOW' - test in aerated SBPOW; 'SBPOW $+\mathrm{N}_{2}$ ' - test in deaerated SBPOW; 'SBPOW $+\mathrm{Cl}$ ' - test in deaerated SBPOW with 100 -fold increased content of chlorides; 'SBPOW +Cl+Q' - test in deaerated SBPOW with 100-fold increased content of chlorides and under heat flux)

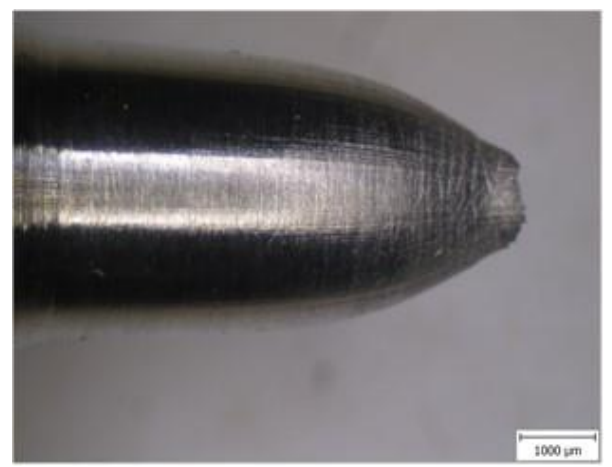

Fig. 9 Example of a sample after SSRT test with typical 'neck' of mechanical fracture

\section{Discussion}

It was difficult to achieve corrosion activation of either material in SBPOW at $90{ }^{\circ} \mathrm{C}$. Only an increase in chloride content with simultaneous action of artificial crevice and polarisation to $\mathrm{E}_{\mathrm{RED} / \mathrm{OX}}$ of an aerated solution allowed activation of austenitic stainless steel 316L. SSRT tests on both materials showed no effect of mechanical rupture of the passive layer in deaerated SBPOW, neither after a 100-fold increase in chloride content, nor in the presence of heat flux.

Localised attack was observed in deaerated bentonite slurry at $90{ }^{\circ} \mathrm{C}$. What was the most detrimental parameter of bentonite slurry in contrast to SBPOW? We can exclude creviceforming particles of bentonite because artificial crevices (O-rings) did not show any effect in SBPOW. Also, mechanical rupture of the passive layer by solid bentonite particles can be discounted, because there was no effect of mechanical strain in the SSRT test, or in the exposure 
of U-bend samples. Influence of additional dissolution of chlorides into the SBPOW at $90{ }^{\circ} \mathrm{C}$ can be also negotiated, since increase of chlorides up to 100 -fold had no effect on formation of localised attack.

There are two most probable effects of solid bentonite on localised corrosion. The surface of bentonite particles is able to adsorb metal ions strongly. It is possible that the passive layer in contact with bentonite can be locally dissolved due to adsorption of metals from the passive layer onto bentonite. Moreover, the same adsorption makes the repassivation of the metastable pit formed more difficult. The open geometry of the pits is also an argument for the effect of bentonite adsorption.

The other effect is the possible presence of thiosulphates, which are well known to cause pitting corrosion of stainless steels. Thiosulphates in the environment are produced mostly by oxidation of sulphides. Sulphides are naturally contained in the bentonite (e.g. as pyrite) or they can be produced by sulphate-reducing bacteria. Microbial activity at $90{ }^{\circ} \mathrm{C}$ is less probable, but production of thiosulphates from natural bentonite sulphides cannot be excluded. Nevertheless, there were detected no thiosulphates in the solution after the exposure, thus if there any microbial activity proceeds, it changes the pore solution composition only locally.

\section{Conclusions}

There was observed no localised corrosion or stress corrosion cracking at $90{ }^{\circ} \mathrm{C}$ in synthetic bentonite pore water. On the contrary, pitting corrosion at $90{ }^{\circ} \mathrm{C}$ in bentonite slurry was observed. This is attributed to the adsorption ability of bentonite particles. Both materials remained free of corrosion attack in deaerated bentonite slurry up to $70{ }^{\circ} \mathrm{C}$.

\section{References}

[1] I. Pospiskova, et al.: Corrosion Engineering, Science and Technology, Vol. 52, 2017, No. S1, p. 6-10, DOI: 10.1080/1478422X.2017.1300379

[2] J. Stoulil, V. Hemmer, V. Šefl, J. Bystrianský: Materials and Corrosion, Vol. 66, 2015, No. 4, p. 342-346, DOI: 10.1002/maco.201307468

[3] J. Stoulil, J. Kaňok, M. Kouřil, H. Parschová, P. Novák: Journal of Nuclear Materials, Vol. 443, 2013, No. 1-3, p. 20-25, DOI: 10.1016/j.jnucmat.2013.06.031

[4] J. Stoulil, et al.: Materials and Corrosion, Vol. 69, 2018, No. 9, p. 1163-1169, DOI: 10.1002/maco.201710014

[5] D. Novikova, M. Kouřil, Š. Msallamová, J. Stoulil, N. Strnadová: Koroze a ochrana materialu, Vol. 60, 2016, No. 3, p. 68-73, DOI: 10.1515/kom-2016-0011

[6] J. Stoulil, Y. R. Carreno, L. Pavlova, M. Kourril, D. Dobrev: Koroze a ochrana materialu, Vol. 60, 2016, No. 5, p. 139-143, DOI: 10.1515/kom-2016-0022

[7] J. Stoulil, D. Dobrev: Koroze a ochrana materialu, Vol. 60, 2016, No. 2, p. 60-67, DOI: $10.1515 / \mathrm{kom}-2016-0010$

[8] J. Stoulil, L. Horáčková, J. Ř́íhová-Ambrožová: Koroze a ochrana materialu, Vol. 58, 2014, No. 2, p. 43-47, DOI: 10.2478/kom-2014-0006

[9] J. Pang, D. J. Blackwood: Corrosion Science, Vol. 105, 2016, p. 17-24, DOI: $10.1016 /$ j.corsci.2015.12.011

[10] R. G. Bell, C. K. Lim: Canadian Journal of Microbiology, 1980, p. 242-245.

[11] J. D. A. Miller: Microbial Aspects of Metallurgy, Springer, Netherlands, 1971.

[12] A. M. Brennenstuhl, T. S. Gendron, R. Cleland: Corrosion Science, Vol. 35, 1993, No. 1-4, p. $699-711$ 
[13]R. C. Newman, W. P. Wong, A. Garner: Corrosion, Vol. 42, 1986, No. 8, p. 489-491

[14]P. Perego, B. Fabiano, R. Pastorino, G. Randi: Bioprocess Engineering, Vol. 17, 1997, p. 103-109

[15]C. Ornek: Performance Characterisation of Duplex Stainless Steel in Nuclear Waste Storage Environment, Dissertation Thesis, University of Manchester, 2015

[16][9.1.2019], K. Chiang and P. Shukla: https://www.nrc.gov/docs/ML1036/ML103620293.pdf

[17] J. Stoulil et al.: Corrosion, Vol. 75, 2019, No. 4, p. 367-376, DOI: 10.5006/2852

[18]R. B. Rebak: Selection of Corrosion Resistant Materials for Nuclear Waste Repositories, Report of Lawrence Livermore National Laboratory No. UCRL-PROC-221893, 2006

[19]B. Kursten, et al.: Corrosion Engineering, Science and Technology, Vol. 46, 2011, No. 2, p. 91-97, DOI: $10.1179 / 1743278210$ Y.0000000022

[20]A. K. Roy, G. A. Henshall, R. D. McCright: Electrochemical Corrosion Studies of Container Materials in Repository-Relevant Environments, Report of U.S. Department of Energy - Office of Scientific and Technical Information No. UCRL-ID-122860, 1995

[21]X. He, D. S. Dunn, A. A. Csontos: Electrochimica Acta, Vol. 52, 2007, No. 27, p. 7556-7569, DOI: 10.1016/j.electacta.2006.12.077

[22]X. He, T. Ahn, T. Sippel: Corrosion of borated stainless steel in water and humid air, Report of U.S. Nuclear Regulatory Commission No. NRC-02-07-006, 2011

[23]T. Sakuragi, S. Yoshida, O. Kato, T. Tateishi: Progress in Nuclear Energy, Vol. 87, 2016, p. 26-31, DOI: 10.1016/j.pnucene.2015.10.008

[24] A. G. Muñoz, D. Schild: Corrosion of austenitic steel in geochemical near-field conditions of high-level radioactive waste rock repositories, In: Proceedings of Eurocorr, Krakow (Poland), 2018

\section{Acknowledgement}

This work was supported by SÚRAO (Czech Radioactive Waste Repository Authority) under Project No. SO2013-088. 